\title{
DEMOKRACJA W RECESJI? DIAGNOZY I PROJEKTY NAPRAWCZE ${ }^{\#}$
}

\section{Irena Pańków*}

Abstrakt

Esej podejmuje kwestie ważne dla współczesnej demokracji. Z raportów instytucji monitorujących jej stan na świecie wyłania się obraz demokracji w recesji. Stanowi on globalne tło do „lokalnych” wyników badań i analiz zawartych w pracy badaczy, których książka stanowi główny przedmiot eseju. Rahat i Kenig badają dwa główne zjawiska współczesnej demokracji: zmierzch partii politycznych i personalizację polityki. Oba zjawiska są paliwem polityki populistycznej. Groźne dla demokracji trendy opisane do roku 2015 nasiliły się później w postaci „wojen kulturowych”, stanowiących zdaniem innych badaczy ślepą uliczkę dla demokracji liberalnych.

Słowa kluczowe: demokracja liberalna, partia polityczna, zmierzch partii, adaptacja partii, populizm, polityczna personalizacja, podejście komparatystyczne

\section{DEMOCRACY IN A RECESSION? DIAGNOSIS AND REPAIR PROJECTS}

Abstract

The essay deals with issues important to modern democracy. From the reports of monitoring its condition in the world a picture of democracy in recession is emerging. It is a global background to "local" research results and analyzes contained in the work researchers whose book is the focus of the essay. Rahat and Kenig are researching the two main phenomena of the modern demonation: the decline of political parties and personalize the policy. Both phenomena they are the fuel of populist politics.

The trends described until 2015, which are dangerous for democracy intensified later in forms of "culture wars", constituting according to other researchers, a dead end for liberal.

Keywords: collective action, cross-national comparison, party adaptation, party change, party decline, political parties, political personalization

\footnotetext{
\# Analizy i refleksje podjęte w tym eseju powstały z inspiracji i dotycza głównie następującej pozycji: Rahat, G., Kenig, O. (2018). From Party Politics to Personalized Politics? Party Change and Political Personalization in Democracies. Oxford: Oxford University Press.
}

* Prof. dr hab. Irena Pańków, Instytut Studiów Politycznych Polskiej Akademii Nauk e-mail: ipank@isppan.waw.pl | ORCID: https://orcid.org/0000-0002-0743-0316 
Wprowadzenie

Od początku huntingtonowskiej trzeciej fali demokratyzacji czyli od 1974 roku1, ponad 90 państw podjęło transformację swoich systemów politycznych w kierunku demokracji. Na przełomie stuleci około 60\% spośród blisko 200 niepodległych państw świata można było uznać za demokratyczne (Diamond 2008).

Pod upływie dwóch dekad XXI wieku z różnych badań wyłania się zgoła odmienny, znacznie mniej optymistyczny obraz stanu demokracji na świecie i w państwach świata. Według brytyjskiego tygodnika „The Economist” wraporcie dotyczącym Indeksu Demokracji 2019, opracowanym przez zespół badawczy The Economist Unit, pod koniec drugiej dekady XXI wieku spośród objętych badaniem 167 państw świata w roku 2019 były tylko 22 pelne demokracje, 54 zostały uznane za „wadliwe” (w tym także Polska czy USA), 37 systemów hybrydowych (np. Ukraina czy Turcja) oraz 54 za systemy autorytarne (np. Rosja, Iran - Flis 2020). J ak podają autorzy raportu, „w pełnych demokracjach mieszka zaledwie 5,7 proc. światowej populacji, w wadliwych demokracjach 42,7 proc., w systemach hybrydowych 16 proc., a w systemach autorytarnych 35,6 proc. ludzkości" (Ibidem). W ocenie autorów raportu, rok 2019 pod względem stanu demokracji na świecie był najgorszym whistorii ich badań, czyli od roku 2006.

Podobne wyniki zawarte są w kolejnych, sukcesywnie opracowywanych od roku 1972 raportach amerykańskiej organizacji pozarządowej Freedom House. Raport Freedom House pod znamiennym podtytułem Freedom in the World 2020: A Leaderless Struggle For Democracy

\footnotetext{
1 Trzecią falą demokratyzacji Samuel Huntington (2009) nazwał przemiany polityczne, gospodarcze i społeczne, które ukształtowały porządek świata w ostatnich dekadach XX wieku. W swojej książce z roku 1991 za początek trzeciej fali demokratyzacji uznał pokojowy zamach stanu w Portugalii z 25 kwietnia 1974 roku. Zamach, dokonany przez głównie młodych oficerów armii portugalskiej, nazywany rewolucją goździków, doprowadził do obalenia dyktatury następcy Antónia Salazara - Marcela Caetana. „Demokratyczne przejście” (democratic transitions) w ujęciu Huntingtona nie ostało się weryfikacji historycznej, bowiem w przypadku szeregu państw postkomunistycznych zakończyło się utrwaleniem systemów na poły czy wręcz całkowicie autorytarnych.
} 
(Repucci 2020) stwierdza, iż rok 2019 był kolejnym 14 już rokiem pogarszania się stanu demokracji na świecie. Proces ten objął 64 państwa na 197 uwzględnionych w rankingu, podczas gdy poprawa stanu demokracji wystąpiła w 37 krajach. I jakkolwiek negatywne tendencje wystąpiły we wszystkich typach reziimów, w największym stopniu dotknęły one państw bliskich czoła rankingu i na samym jego dole. Ponad połowa państw, które w roku 2009 były w raportach Freedom House uznawane za w pełni wolnelub nie wolne doświadczyła w ciągu drugiej dekady XXI spadku netto demokracji i wolności (Ibidem).

Można zatem przyjąć, iż fala demokratyzacji, jaka przetoczyła się przez różne regiony świata w ostatnich dekadach XX wieku i w pierwszych kilku latach XXI wieku, w kolejnych latach nowego stulecia zaczęła dość szybko wygasać i mimo podejmowanych różnych prób prodemokratycznych korekt (tzw. „kolorowe rewolucje” I dekady czy arabska wiosna na początku drugiej) trend odchodzenia od liberalnej demokracji nie tylko nie uległ zmianie, ale z każdym rokiem się nasila.

W rezultacie demokracja według wzorca liberalnego nie tylko nigdy w historii nie stała się dominującym ustrojem, a tym bardziej rozwiązaniem uniwersalnym, ale w ostatnich kilkunastu latach znajduje się w permanentnym odwrocie i na przełomie drugiej i trzeciej dekady XXI wieku staje się zjawiskiem coraz bardziej marginalnym, by nie rzec niszowym. I działo się to jeszcze przed głębokim kryzysem gospodarczospołecznym, wjaki wchodzi świat na skutek pandemii wywołanej koronawirusem covid-19 w roku 2020, który zapewne nie przyczyni się do wzmocnienia demokracji w wielu państwach zarówno rozwiniętych, jak i rozwijających się.

Stan demokracji, przynajmniej w myśli liberalnej utożsamianej z historycznie ukształtowaną demokracją liberalną, jest rzecz jasna przedmiotem nieustającego dyskursu od zarania jej istnienia (Antoszewski 2016; Held 2010). J akkolwiek dyskurs ten toczy się nieprzerwanie, na ogół ulega ożywieniu nie utedy, kiedy demokracja ma się względnie dobrze, a wtedy, kiedy staje się ona przedmiotem krytyki, zwłaszcza zaś 
kiedy jest kontestowana czy zgoła podważana. A dzieje się tak utedy, gdy demokracja realna wykazuje zasadnicze deficyty i dysfunkcje, które prowadzą do zjawiska, określonego przez Fukuyamę jako recesja demokracji. Wzajemne relacje pomiędzy stanem demokracji a refleksją na jej temat są bardzo złożone, nie są wszakże symetryczne: można zaryzykować tezę, iż częściej dyskurs nie nadąża za wyzwaniami praktyki niż odwrotnie. I tak jest zapewne w ostatnich latach.

Tym istotniejsze jest postawienie trafnej diagnozy, identyfikującej podstawowe charakterystyki stanu demokracji, najlepiej w ujęciu porównawczym, oraz ich dynamikę. Powinno to umożliwić wykrycie jakichś wzorców, tendencji w odniesieniu do historycznie zachodzących procesów. Wymaga to uwzględnienia podstawowych wymiarów, przy pomocy których można charakteryzować realnie istniejącą demokrację w różnych systemach politycznych.

Aby możliwe było przejście od diagnozy stanu demokracji do prób wyjaśnienia zachodzących procesów konieczne jest uwzględnienie szeroko pojmowanego kontekstu, obejmującego podstawowe czynniki wpływające na stan demokracji i jej jakość, zarówno bezpośrednio, jak i poprzez różnorakie zmienne zapośredniczające.

W świetle tych diagnoz i toczącego się wokół nich dyskursu bardzo istotne jest pytanie, jaką rolę w procesie erozji demokracji i odwrotu od demokratyzacji odgrywa dynamika/ ewolucja roli partii politycznych jako jednej podstawowych instytucji, tworzących systemy polityczne państw. To właśnie jakość systemów partyjnych i tworzących je partii politycznych co najmniej kształtuje, albo i przesądza ojakości demokracji i stopniu demokratyzacji poszczególnych państw, co oczywiście w dużym stopniu odnosi się do nowych demokracji i nowych systemów partyjnych (Nalewajko 1997).

Równie ważne pytanie dotyczy kolejnej kwestii odnoszącej się do funkcjonowania systemów politycznych, jakim jest rola przywództwa. W szczególności stopnia spersonalizowania systemu politycznego, politycznych mechanizmów i procesów podejmowania decyzji politycznych 
a w konsekwencji - sposobów uprawiania polityki i realizowania konkretnych polityk.

Demokracja jako kulturowo i historycznie uwarunkowany projekt polityczny nieustannie narażonajest na wyzwania i kryzysy. Pomimo to - a właściwie zapewne właśnie dlatego - przynajmniej zdaniem jej obrońców jest to projekt z natury otwarty na innowacje i podatny na zabiegi ozdrowieńcze? .

Skala wyzwań, wobec których stoi w ostatnim okresie demokracja sprawia, że jej badacze nierzadko porzucają wygodne nisze obiektywizmu, włączając się do poszukiwań mających służyć jej terapii. Rekomendacje oczywiście budowane są na podstawie diagnoz. A te różni natężenie krytyki co do słabości i dysfunkcji demokracji. Zalecenia różni stopień radykalizmu co do propozycji zmian oraz optymizmu co do szans powodzenia proponowanych rozwiązań. Wielu badaczy, krytycznych wobec obecnego stanu demokracji liberalnej, jest przekonanych o jej wartości. „Demokracja liberalna ma własną kulturę, którą należy cenić wyżej niż kultury odrzucające wartości demokratyczne” (Fukuyama 2019: 204).

Współczesne demokracje, jak wiadomo, borykają się z różnorodnymi problemami i narastającymi zagrożeniami. Słabości, deficyty i zagrożenia są też stałym przedmiotem i refleksji i badań. Demokracja „niskiej jakości” doczekała się wielu opracowań i dopracowała własnych miar, takich jak poziom korupcji, deficyt rządów prawa, itd. Działają instytucje w sposób ciągły badające i monitorujące jakość demokracji, także trendy zachodzące w skali globalnej (Trzciński 2016). Katalog niedomogów, błędówi chorób opisany jest w ogromnej liczbie raportówi książek. Zależnie od koncepcji autorskiej i perspektywy badawczej przyczyny

\footnotetext{
${ }^{2}$ W tym obszarze, także na polskim rynku, mamy wiele interesujących lektur. Nadzieje „ozdrowieńcze” dla demokracji lokowane zazwyczaj w demokracji partycypacyjnej przesunęły się w ostatniej dekadzie w kierunku demokracji deliberacyjnej. I tu warto odnotować ważną, sumującą bogaty dorobek w tych dwóch obszarach, pozycję: Janusz Grygieńć (2017) Demokracja na rozdrożu. Deliberacja czy partycypacja polityczna? By odpowiedzieć za zawarte w podtytule pytanie Autor skrupulatnie analizuje argumenty, które pozwalają sądzić, że dla dobra praktyki demokratycznej ważne jest łączenie partycypacji z deliberacją.
} 
tego stanu rzeczy są różnie lokowane, różny też jest stopień optymizmu co do tego, czy recesję demokracji da się powstrzymać. Często podnoszona jest zawodność mechanizmu reprezentacji, niska jakość klasy politycznej, stan partii politycznych. Po drugiej stronie mamy obywatela „niskiej jakości” zjego apatią i ignorancją.

Zgoda badaczy jest niemal powszechna: dotychczasowy model demokracji liberalnej, oparty o mechanizm reprezentacji legitymizowany za pośrednictwem cyklicznie organizowanych konkurencyjnych wyborów, historycznie ulega wyczerpaniu. J est coraz mniej atrakcyjny jako propozycja ideowa, mówi się więc kryzysie idei i wyobraźni liberalnej (Lilla 2016). Model ten traci na znaczeniu, gdyż jest niewydolny jako mechanizm łączący społeczeństwo z polityką. Mówiąc metaforycznie koło przemian społecznych nie zazębia się wystarczająco z kołem instytucji politycznych, wśród których decydującą rolę odgrywały partie polityczne.

Coraz większego znaczenia w polityce nabierają inni niż partie polityczne aktorzy, zmieniają się mechanizmy funkcjonowania sfery polityki. Przestrzeń, zajmowaną od początku formowania się systemów politycznych opartych na rywalizacji partii politycznych przez te partie, w coraz większym stopniu wypełniają przede wszystkim pojedynczy politycy, których już w XVI w Machiavelli nazywał przedsiębiorcami politycznymi (Pańków, Pańków 2010). J edni z nich używając partii jako wehikułu do zdobywania i utrzymywania władzy. Inni, odrzucając partie, już to z pozycji autorytarnych, już to odwołując się do retoryki obywatelskiej, tak czy siak sięgając po instrumentarium właściwe dla populizmu. Przestrzeń, przewidzianą dla polityki, poza jednostkami, aspirującymi do pozycji liderów politycznych czy trybunów ludowych, w coraz większym stopniu zagospodarowują też aktorzy inni niż politycy, czy to partyjni, czy pozapartyjni: mass media, ruchy polityczne, ruchy obywatelskie, administracja i ciała subpolityczne (Rosanvallon 2011). 
Demokracje pierwszych dekad XXI wieku

Populizm co prawda na stałe towarzyszy demokracji, dzieje się to wszakże $\mathrm{z}$ różnym natężeniem ${ }^{3}$. J est też przez nią neutralizowany raz lepiej, raz gorzej. W optyce badaczy izraelskich populizm jest pochodną dwóch procesów. W kryzysie demokracji pierwszych dekad XXI wieku staje się wyzwaniem najpoważniejszym, związany jest bowiem z wyraźnym zwrotem ku autorytaryzmowi, osłabiając i wypychając mechanizmy i instytucje właściwe dla systemu demokracji liberalnej.

Taką właśnie tezę przyjmują za punkt wyjścia swoich badań autorzy omawianej pracy. „Populizm i personalizacja to dwa główne trendy w polityce pierwszych dekad XXI wieku. Pytania o relacje między nimi są kluczowe dla rozumienia obydwu: do jakiego stopnia są to niemal identyczne bliźniaki, gdyż oba te zjawiska są skierowane przeciwko instytucjom i działają na korzyść charyzmatycznych liderów?" (Rahat, Kenig 2018: 262).

Na czoło przemian wysuwają się dwa procesy: postępujący na osi czasu zmierzch partyjności (partyness) polityki i powolny wzrost personalizacji polityki. Te zjawiska, rozpatrywane przez autorów we wzajemnym powiązaniu, sprawiają, że system powiązań społeczeństwa z partiami i polityką znacząco się przeobraża. Historycznie, partie były głównym ogniwem łączenia preferencji (interesów i przekonań) obywateli z polityką, ich artykulacji i reprezentacji. Teraz ta funkcja w coraz większym stopniu przesuwa się w kierunku liderów, zarówno partyjnych, jak i pozapartyjnych - co zazwyczaj skutkuje populizmem i związanym z nim nowym sposobem funkcjonowania polityki. Prowadzą one do osłabienia głównych instytucji politycznych: państwa, rządów prawa oraz mechanizmów i narzędzi demokratycznych rozliczeń osób uprawiających politykę.

3 "Tli się i raz po raz wybucha nurt populistyczny" - stwierdza Włodzimierz Wesołowski (2000: 172) w odniesieniu do pierwszej dekady demokracji w Polsce. Kilkanaście później Maciej Gdula (2018) opisując życie polityczne małego miasta twierdzi, że nie chodzi o „populizm” lecz „nowy autorytaryzm”. 
Studium porównawcze 26 demokracji

W tym opracowaniu skupię się przede wszystkim na przedsięwzięciu badawczym , które bezpośrednio lub pośrednio odpowiada na pytania o stan demokracji. Autorzy zastanawiają się co jest nie tak z demokracją i - przynajmniej do pewnego stopnia - jaki jest na to ratunek. Praca Gideona Rahata i Ofera Keniga (2018) oferuje spojrzenie z „lotu ptaka” na główne, ich zdaniem, procesy zachodzące we współczesnych demokracjach na przestrzeni blisko półwiecza obejmującego końcowe dekady XX wieku oraz półtora dekady XXI.

Obszar pomiędzy sferą realnej polityki a sferą szeroko pojmowanej świadomości społecznej i społecznych postaw w systemach demokratycznych tradycyjnie zagospodarowywany był - i zapewne jest nadal, choć mamy tu do czynienia z dynamicznie zachodzącymi procesami zmian - przez systemy partyjne. Dotyczy to i starych, i nowych demokracji. W opracowaniu dotyczącym stanu partii w Polsce pada teza odnosząca się do ostatnich lat - „Trudne czasy dla partii, trudne czasy dla demokracji” (Marczewski 2017: 71-72). I jak się okazuje jest to stan w istocie powszechny w krajach uznawanych za demokratyczne, co zostało rzetelnie udokumentowane w pracy izraelskich badawczy.

Rozmach - to pierwsze wrażenie, jakie narzuca się przy lekturze książki From Party Politics to Personalized Politics? Party Change and Political Personalization in Democracies. J est to rozmach empiryczny i ambitne przedsięwzięcie teoretyczne zarazem. Empirycznie, bo pod lupą badaczy znalazło się 26 demokracji ${ }^{4}$. Badaniem objęto okres od lat 70. (niektóre dane sięgają lat 60.) XX wieku do roku 2015. I choć ścisła

\footnotetext{
4 Badania objęły państwa zaliczane do pierwszej i drugiej fali demokratyzacji, o utrwalonej demokracji, zarówno europejskie (Austria, Belgia, Dania, Finlandia, Francja, Islandia, Irlandia, Luksemburg, Niderlandy, Niemcy, Norwegia, Szwecja, Szwajcaria, Wielka Brytania, Włochy), jak pozaeuropejskie (Australia, Izrael, Japonia, Kanada, Nowa Zelandia); ponadto państwa zaliczane do trzeciej fali demokratyzacji (jej wczesnej fazy czyli Grecja, Portugalia, Hiszpania) oraz późnej fazy (Czechy, Polska, Węgry). Do badań nie włączono państw o systemach czysto prezydenckich, takich jak USA, gdzie wzorce dotyczące badanego w omawianej pracy procesu personalizacji siłą rzeczy charakteryzują się daleko posuniętą specyfiką.
} 
dokumentacja kończy się w roku 2015, książka zawiera również odniesienia do późniejszych turbulencji demokracji, zasadniczo potwierdzających zidentyfikowane w pracy tendencje, a niekiedy je wręcz wzmacniające. Badacze sięgnęli do bez mała wszystkich dostępnych źródeł w postaci wyników badań empirycznych przeprowadzonych w uwzględnionych w studium państwach. Nie mniej solidna jest ich praca przy biurku, autorzy zgromadzili i przeanalizowali bowiem imponująco rozległą wiedzę o badanych zjawiskach, czego dowodem bardzo obszerna i pod każdym względem reprezentatywna bibliografia literatury przedmiotu (32 stron samej bibliografii, 30 stron apendixów, rozległy i bardzo użyteczny indeks rzeczowy).

Przypatrzmy się zatem głównej strategii metodologicznej izraelskich badaczy; jest to jednoczesna obróbka, integracja i utórna interpretacja danych empirycznych oraz odniesienie rezultatów tej analizy do istniejących teorii. Deklarowanym przez autorów omawianej pracy celem była utórna analiza i zintegrowanie dostępnych danych oraz wprowadzenie uzyskanych wyników w obieg międzynarodowych badań porównawczych. To zadanie zostało skrupulatnie wykonane. I autorzy mają prawo do formułowania oceny, iż dokonali ważnego wkładu w badanie ważnych dla funkcjonowania demokracji zjawisk i tendencji: „nasze wyniki nie są słabe” (Rahat, Kenig 2018: 257).

Dotyczy to obu ujęć podjętych badań, synchronicznego i diachronicznego. Po drodze konieczne było również rozwiązanie przez autorów studium dylematu dotyczącego tego, co specyficzne i tego, co wspólne w każdym z wymiarów. I właśnie by zapewnić porównywalność i umożliwić zintegrowanie różnorodnych i częstokroć o różnej jakości danych proponują wspominany już zabieg określony jako ,jakościowe kalibrowanie" pierwotnych danych. Polegało to na utworzeniu 5-cio stopniowej skali (właściwiej byłoby mówić o symetrycznej skali trzystopniowej z punktem 0, zastosowano bowiem skalę od -2 do +2) dla badania natężenia każdego z dwóch procesówi przyjęciu łącznie zestawu ponad 20 
wskaźników, po 12 dla scharakteryzowania każdego z badanych procesów, pogrupowanych w 3 wymiarach.

To pierwsze zadanie można uznać za udane, pod warunkiem wszakże, że zaakceptujemy główną metodą procedury badawczej jaką jest kalibrowanie. Trzeba mianowicie mieć na względzie pytanie, czy - a jeśli tak to do jakiego stopnia - technika kalibrowania, zastosowana w odniesieniu do tak niejednorodnych zjawiskjak dynamika procesów politycznych w ponad dwudziestu państwach, w dodatku przebiegających na przestrzeni bez mała półwiecza, nie pozostawia zbyt wiele pola dla na poły arbitralnych rozstrzygnięć.

Innymi słowy, wyzwaniem jest tu kwestia przekładania charakterystyk jakościowych oraz parametrów i statystyk zastosowanych w pierwotnych badaniach na takie kategorie, które dają podstawy do ich ujęcia komparatystycznego we utórnej analizie wyników badań. A przecież rzutuje to w zasadniczy sposób na prawomocność rezultatów badawczych oraz kierunki ich interpretacji. I w odniesieniu do badanych przez autorów pracy procesów łatwiej zaakceptować wywiedzione przez nich tezy odnoszące się do kierunku czyli tendencji tych procesów, niż co do natężenia, mocy tych tendencji.

J eszcze więcej wątpliwości budzi próba syntezy materiału teoretycznego, zwłaszcza jeśli zgodnie z deklaracją autorów celem jest wyjście poza generalizacje. Do jednego koszyka zbierane są koncepcje różnych autorów i autorek badających zjawiska podobne - ale niekoniecznie takie same - do tych, którymi się zajmują autorzy omawianej pracy. Ich znaczny stopień samoświadomości metodologicznej oraz teoretycznej sprawia, iż pozostają oni w żywym dialogu z teoriami, hipotezami i wynikami badań empirycznych. Czytelnik uzyskuje więc bonus w postaci obszernego kompendium wiedzy z zakresu politologii i socjologii politycznej odnoszącej się analizowanych procesówi ich kontekstu. Z drugiej strony może pogubić się w nadmiarze teorii i hipotez i niejednokrotnie nie ma jasności, które z nich są wiodące dla postępowania badawczego. W sumie praca ma w przeważającym stopniu charakter diagnostyczny 
i stąd czytelnik nie powinien spodziewać się głębszych, bardziej syntetycznych perspektyw teoretycznych.

Wypada, choć pokrótce, zrelacjonować treść i główne tezy omawianej pracy. J ej autorzy badają dwa, powiązane ze sobą zjawiska - charakteru tego powiązania dotyczy w istocie główny problem badawczy pracy i głównajej teza - a mianowicie postępujący zmierzch partii politycznych i co za tym idzie polityki partyjnej (partyness) oraz wzrost personalizacji polityki. Przeprowadzając, po uprzednim kalibrowaniu pierwotnych wyników badań tych procesów, ich wtórną analizę identyfikują ogólny trend, który traktują wręcz jako prawidłowość, który polega na stopniowo przebiegającym przechodzeniu systemów demokratycznych badanych państw od „partiokracji do liderokracji”.

Losy partii w poszczególnych krajach są oczywiście różne, wszelako w świetle relacjonowanych badań, począwszy od lat 70. XX wieku przede wszystkim na skutek słabnięcia linii społecznych podziałów, partie, jako główne instytucje za pośrednictwem których funkcjonują mechanizmy demokracji tracą na znaczeniu. Ich ewolucja przyśpiesza, najpierwprzekształcają się w partie typu catch-all, a następnie w partie kartelowe. Przy czym to nie losy poszczególnych partii i systemów partyjnych są przedmiotem zainteresowania badaczy ale właśnie ten ogólny trend, rozpatrywany w kilku wymiarach i mierzony przy pomocy całego zestawu (każdy proces 12) skonstruowanych przez badaczy, z użyciem procedury kalibrowania, wskaźników.

Wynikająca z przemian społecznych i politycznych nowa polityka oparta jest bodaj przede wszystkim na ofercie tożsamościowej proponowanej przez liderów, która ma charakter symboliczny i emocjonalny, w konsekwencji czego klasycznie definiowany interes obywateli i ich grup schodzi na dalszy plan. W rezultacie rozszerza się dogodna przestrzeń do zagospodarowania przez populizmy i populistów. Uruchamiane przez populistycznych liderów emocje i urazy, połączone z populistyczną polityką budowania poczucia godności trafiają na podatny 
grunt i uzyskują wzmocnienie poprzez upowszechnianie się podobnych zapatrywań i postaw w społeczeństwie (Fukuyma 2019).

Te głębokie transformacje przekonań i postaw, zręcznie wzmacniane przez populistycznych manipulatorów, rodzą podziały przybierające postać wojny plemion i sprzyjają jej dalszej eskalacji (Markowski 2019). Zmiany te mogą wręcz przybierać formę swoistego „paradoksu demokratycznego" który z kunsztem socjologicznym i zrozumieniem właściwym socjologii humanistycznym zrelacjonowała Arlie Hochschild (2017) w pracy Obcy we wlasnym kraju. Gniew i żal amerykańskiej prawicy $\mathrm{w}$ odniesieniu do ewolucji postaw spolecznych prawicowego elektoratu w Stanach Zjednoczonych ${ }^{5}$.

Przestrzeń opuszczaną przez partie wypelniają media, pojedyncze osoby, aktywizuje się sektor organizacji i ciał sub-politycznych (Rosanvallon 2011) ${ }^{6}$. Demokracja oparta na reprezentacji za pośrednictwem systemu partyjnego staje się coraz bardziej płytka (wydrążona). W rezultacie obywatel traci zaufanie i poczucie lojalności politycznej względem instytucji składających się na system demokratyczny. Coraz bardziej nośne staje się kwestionowanie elit politycznych, upowszechniają się anty-elitarne i anty-partyjne nastroje, podsycane nie tylko przez populistycznych liderów, ale i przez nie stroniące od populizmu partie. Część tej przestrzeni rzecz jasna zagospodarowują właśnie te partie, które nie wahają się sięgać do retoryki i instrumentarium populistycznego. Siła mobilizacyjna polityki tożsamości i walki plemion zdaje się uchodzić uwadze badaczy diagnozujących powiązanie zmierzchu partii ze wzrostem personalizacji. Zapewne dlatego, że w okresie objętym

\footnotetext{
5 Obywatele głosują wbrew własnym interesom w imię symbolicznego interesu tożsamościowego i odzyskiwania poczucia godności. Polityczny populizm wydobywa głębokie pokłady wojen kulturowych i uruchamia destrukcyjny mechanizm walki plemion.

${ }^{6}$ Zdaniem autora, współcześnie, demokracja nie znika lecz przemieszcza się, zaczęła się rozwijać poza obszarem elektoralno-przedstawicielskim. A tytułowa kontr demokracja „nie jest tu przeciwieństwem demokracji. To raczej jedna forma demokracji, która przeciwstawia się innej formie demokracji, demokracja władz pośrednich rozsianych po całym ciele społecznym, demokracja zorganizowanej nieufności pod adresem demokracji legitymizowanej procesem wyborczym" (Rosanvallon 2011: 11).
} 
analiza procesy te nie występowały z takim natężeniem, jaki ma miejsce w ostatnich latach (por. Markowski 2019)

Przyjęte w pracy Rahata i Keniga międzynarodowe ujęcie komparatystyczne o stosunkowo długim szeregu czasowym, z zastosowaniem obszernego zestawu wskaźników, stanowiło nie lada wyzwanie, nic więc dziwnego, że autorzy dzielą się swoimi wątpliwościami i zastrzeżeniami dotyczącymi przyjętej przez nich metodologii. Autokrytycyzm odnosi się do wielu aspektów ich badań, takich jak: dostępność danych (zwłaszcza badań z wcześniejszych okresów); wiarygodność i jakość danych (stosunkowo wysoka jakość danych dotyczących zmienności i przepływów elektoratu; inne są i trudniej dostępne i trudniejsze do porównania); porównywalność - jak zintegrować rozproszone w czasie i przestrzeni dane. I autorzy są świadomi, że „dane nie są idealne”, ale świadomość ta praktycznie nie interferuje znacząco w przebieg procesu badawczego. W badaniu świadomie pominięte są takie aspekty partyjności, jak ich finanse i źródła finansowania, charakterystyki aparatu partyjnego czy dostęp partii do mediów.

Przyjęte wskaźniki partyness dotyczą takich charakterystyk, jak: partyjne zaplecze ministrów, partyjne zaplecze parlamentarzystów, członkostwo w partiach, relacje z grupami interesów i związkami zawodowymi oraz relacje partii na poziomie krajowym z partiami na poziomie regionalnym i lokalnym.

Ważnym i skądinąd powszechnie badanym wskaźnikiem jest uczestnictwo w wyborach i partyjna lojalność wyborców. W świetle przytoczonych danych wiarygodnie udokumentowany został spadek wskaźnika partyjności w społeczeństwie i w obszarze relacji partii ze społeczeństwem. Wskaźnik partyjności w gremiach elitarnych utrzymany jest na mniej więcej stałym poziomie.

Przez odwołanie się do klasycznych teorii można więc powiedzieć, że mamy do czynienia z dawno rozpoznanymi zjawiskami takimi jak alienacja elit politycznych i oligarchizacja partii. Schyłek partyness na regionalnym i lokalnym poziomie i rozchodzenie się wzorów głosowania 
partyjnego na różnych szczeblach wpisuje się w ogólniejszą prawidłowość postępującego słabnięcia zdolności koordynacji wewnętrznej w partiach.

J ednocześnie w sferze realnej polityki widoczny jest duży ruch: partie upadają, przekształcają wewnętrznie, niemal z dnia na dzień powstają nowe. Ogólny trend spadku znaczenia partii w społeczeństwie nie oznacza wszakże, że są one kwestionowane jako organizacje w parlamentach i jako formalne instytucje wystawiające kandydatów w wyborach.

Autorzy rekonstruują dwa typy sposobów reagowania przez partie na te wyzwania, a przez to dwie perspektywy, w których procesy przemian partii są lokowane. J est to strategia adaptacyjna, jej odzwierciedleniem byłby stosunkowo niewielki spadek wskaźnika partyness. Z kolei inercja, oznaczająca brak reakcji i działań przystosowawczych ze strony partii, prowadzi do ich upadku i zaniku, co odzwierciedla duży spadek wskaźnika partyjności.

Perspektywa zmierzchu partii jest bliższa tezy postawionej przez autorów omawianej pracy, choć tė̇ często podkreślają, że faktycznie zachodzą oba procesy, a wartość dodaną swojej pracy upatrują w pokazaniu tego, co jest w głębi (pod powierzchnią) procesu głównego. Ich zdaniem bowiem na powierzchni zjawisk w procesy funkcjonowania partii interferują różne czynniki, takiejak kultura polityczna czy regime structure, a także czynnik ludzki, czyli podejście aktorów partyjnych, którzy mogą podejmować różne strategie indywidualne, ale te kwestie nie są przedmiotem ich badań.

Schyłek partyjności jest wyraźny w relacjach wertykalnych między partiami, a organizacjami oraz partiami, a wyborcami. Słabną związki ze społeczeństwem, zarówno bezpośrednie, jak i pośrednie. Powiększa się także przepaść miedzy wzorami partyjnego głosowania na linii centrum-region. Adaptacja obejmuje wymiar horyzontalny na poziomie elit parlamentarnych i rządowych. J ednocześnie, zdaniem autorów, 
spójność partii i możliwość podejmowania skutecznych kolektywnych akcji maleje.

Pytania o relacje między zmierzchem partii i wzrostem natężenia personalizacji polityki są kluczowe dla rozumienia obydwu. Populistyczna wrogość wobec sfery polityki i instytucji politycznych z reguły działa na korzyść charyzmatycznych liderów. Zazwyczaj obraca się także przeciwko partiom politycznym głównego nurtu, chyba, że liderzy poszczególnych partii są w stanie skutecznie przejąć populistyczne instrumentarium i za jego pomocą czy to zneutralizować wrogość wobec własnej partii, czy też obrócić tę wrogość przeciw konkurentom. Jakiego rodzaju zależności zachodzą zatem między tymi dwoma procesami? Czy są to zjawiska przyczynowo powiązane, czy też obydwa odnieść należy do wspólnych źródeł: w kulturze? W strukturze społecznej? W głębszych pokładach kultury politycznej?

Autorzy omawianej pracy dowodzą, że wszystkie zjawiska składające się na dwa główne procesy dotyczą powiązań między polityką a społeczeństwem, ale nie jest jasne - także dla nich - wjaki sposób są one ze sobą powiązane. Podczas gdy partie słabną, wzrasta personalizacja. J ednakże nie jest to sytuacja, którą opisuje model gry o sumie ściśle zerowej. I dostrzegają to sami autorzy.

Co więcej, z ich badań wynika, że niekoniecznie w przestrzeń, uwalnianą przez słabnące partie, swobodnie mogą wkraczać inni aktorzy. Ponadto wzrastająca personalizacja nie tylko nie musi oznaczać strat dla partii, może nawet przyczynić się do ich wzmocnienia. Tak czy siak, tendencja do postępującej personalizacji, w ich przekonaniu, stanowi bardzo poważne wyzwanie dla partii.

J ednakże, jak utrzymują, partie były, są i pozostaną rozwiązaniem kwestii kolektywnego działania i kanalizowania indywidualnej energii dla dobra zbiorowości. A zatem - konkludują - partie mogą poradzić sobie z tendencją do personalizacji procesów politycznych, a nawet wykorzystywać to zjawisko na swoją korzyść. 
Roland Inglehart na podstawie systematycznie prowadzonych i szeroko zakrojonych badań porównawczych dokumentuje przemiany wartości (od materialistycznych do wartości post-materialistycznych). Tworzy też globalną mapę rozkładu wartości na dwóch osiach: wartości tradycyjne - wartości świecko-racjonalne oraz wartości przetrwania wartości indywidualnej ekspresji. Wartości świecko-racjonalne i wartości indywidualnej ekspresji, zgodnie z wynikami badań, są dodatnio skorelowane z wartościami demokracji (Inglehart 1977; Inglehart, Pippa, 2009). I zestawienie to dało interesujący wynik: autorzy studium dowodzą, iż społeczeństwa silniej zindywidualizowane są bardziej odporne na spersonalizowaną (potencjalnie populistyczną) politykę niż społeczeństwa bardziej tradycyjne, o silniejszym nastawieniu kolektywnym.

Niezależnie od tych zastrzeżeń autorzy omawianej pracy podtrzymują swoją tezę, że między dwoma zjawiskami, jakimi są zmierzch partii i wzrost personalizacji w sferze polityki, zachodzi swego rodzaju ujemna korelacja: im więcej objawów zmierzchu partii tym większe natężenie personalizacji. Ale wiedzą także o tym, że w tym zakresie nie ma jednoznacznego i powszechnego wzorca.

Uznajmy wstępnie, że personalizacja polityki to przejaw - a może efekt - populistycznego mechanizmu łączenia społeczeństwa z polityką. J est to proces będący, przynajmniej początkowo, następstwem słabnięcia roli partii, w ostatnich latach są to tendencje wzajemnie się zasilające i postępujące jednocześnie. Ale partie były i są podstawowym dla polityki łącznikiem ze społeczeństwem, przede wszystkim jako organizator zbiorowego działania. W tym sensie nie są i nie mogą być kwestionowane jako niezbywalny element systemu parlamentarnego i jako instytucje formalnie wyłaniające i wystawiające kandydatów w wyborach, nawet jeśli nie mają w tym względzie monopolu, co jest m.in. uzależnione od przyjętych w danym państwie regulacji.

Przy tym wyniki dotyczące badań nad personalizacją są bardziej jednoznaczne. Rośnie zatem pole działania dla tradycyjnych liderów par- 
tyjnych i nowych przedsiębiorców politycznych, o jakich pisał już Machiavelli (Pańków, Pańków 2010). I tym samym poszerza się przestrzeń dla mechanizmów populistycznych. Zła pogoda dla polityki partyjnej to zarazem dobra pogoda dla populizmu i polityki spersonalizowanej. Na krótką metę polityk odwołujący się do populizmu może być bardziej efektywny w zdobywaniu władzy i jej utrzymywaniu, może przyciągać i integrować grupy wcześniej wykluczone i zmarginalizowane - ale kiedy traci popularność, wzrasta ryzyko pogłębiania się alienacji społecznej i politycznej, a osłabione czy wręcz zanikające tradycyjne partie przestają być zdolne do kanalizowania narastającej frustracji. Może to prowadzić do nasilenia i upowszechniania postaw i zachowań antysystemowych, a w rezultacie wiedzie do dalszej erozji systemu partyjnego.

Na czym zatem polega zidentyfikowana przez autorów tendencja do personalizacji polityki i sam jej fenomen? Przyjęta w omawianej pracy definicja personalizacji określa ją jako „proces, w którym w procesie politycznym rośnie polityczna waga aktora indywidualnego i spada znaczenie (centrality) grup politycznych (partii)" (Rahat, Kenig 2018: 117). Tak rozumiana personalizacja byłaby wyrazem schyłku znaczenia politycznych kolektywów, ale też konsekwencją przesuwania się ciężaru polityki od meritum do osoby polityka, czego rezultatem z kolei jest intymizacja oraz tabloidyzacja polityki. W rezultacie polityka w coraz większym stopniu staje się spektaklem, ze wszystkimi tego konsekwencjami. J est to walnie wspierane przez mediatyzację polityki, odbywa się ona nie tyle w parlamentach i innych instytucjach państwa, co za pośrednictwem kształtowanego przez media wizerunku polityków.

Sprzyjają temu głębokie zmiany kulturowe, prowadzące do podważenia tradycyjnych zbiorowych tożsamości. W świecie Zachodu - a przecież demokracje tu powstały i ciągle jeszcze tu trwają - wyzwaniem dla zbiorowych tożsamości jest indywidualizm, lub - jak chcą inni - zgoła hiperindywidualizm, który sprawia, że polityka staje się - choć chyba coraz mniej istotną - składową jednostkowego wyboru stylu życia. 
„Staliśmy się hiperindywidualistycznym społeczeństwem burżuazyjnym i to pod względem materialnym, jak dogmatów kulturowych" (Lilla 2018: 44). Czy przybliża nas to do odpowiedzi na pytanie jak personalizacja polityki ma się do zwiększającej się indywidualizacji życia? Tego rozstrzygnięcia omawiana praca nie oferuje.

Przytoczona wcześniej definicja wskazywałby jednak na genetyczny związek fenomenu personalizacji ze zmierzchem partii. Nie ma w niej wszakże genus proximum, przywołującego zjawisko szersze, którego badane tendencje byłyby elementem, przejawem. Można więc przyjąć, że inne, potencjalne przyczyny zidentyfikowanych tendencji to jednak zaledwie dopływy boczne w głównym nurcie powiązań między zmierzchem partyjności i wzrostem czynnika personalizacji. Wątpliwości interpretacyjne mogą brać się z tego, że w omawianej pracy personalizacja jest rozumiana specyficznie, przypuszczalnie zbyt szeroko i nie intuicyjnie, co może prowadzić do nietrafnych wniosków.

Podobnie jak partyness, tak i personalizacja badana jest w kilku wymiarach i za pomocą wielu wskaźników. Wymiary te to: personalizacja instytucjonalna, medialna i behawioralna. Instytucje rządowe i pozarządowe reformowane są na korzyść aktorów indywidualnych. W świetle wykorzystanych w omawianej pracy danych taka tendencja jest widoczna m.in. w prawie wyborczym, w określaniu kompetencji oraz władzy premiera wobec członków rządu w większości uwzględnionych w badaniu państw, choć występujących z różnym natężeniem i z różnym rozłożeniem w czasie. Także w innych organizacjach reformy zmieniają stosunki władzy miedzy liderem, a jej członkami na rzecz liderów.

Najłatwiej można dostrzec postępującą nieubłaganie personalizację medialną polityki, zarówno w mediach kontrolowanych przez władzę, jak i w od niej niezależnych, bowiem media ze swej natury zgoła wymuszają zwrot uwagi z kolektywu, jakim jest partia polityczna, na jej liderów. A ci, poza mediami tradycyjnymi, właściwymi dla ery nowoczesnej, mają do dyspozycji niewyczerpany repertuar nowych mediów ery ponowoczesnej o niemal nieograniczonej sile oddziaływania. I dla znacznej 
części spośród nich media społecznościowe nie tylko stają się podstawowym narzędziem uprawiania polityki, ale można odnieść wrażenie, że politykę tę zastępują, jak sugeruje koncept postpolityki.

W jaki sposób rezultaty referowanych badań - jeśli są trafne - i opisywane przez nie tendencje wpływają najakość demokracji? Autorzy nie udzielają prostych odpowiedzi na to pytanie. Stawiają na to, że duża energia widoczna w polityce spersonalizowanej, osłabiająca lub wręcz niszcząca partie polityczne, zostanie włączona w nurt życia partyjnego. Czytelnik nie dowiaduje się, jak mogłoby się to dokonać.

Rekomendacji „terapeutycznych” być może należy szukać w różnych porządkach. Pomysły uzdrowienia demokracji są mniej lub bardziej radykalne. J ak wiadomo, jedni badacze stawiają na demokrację partycypacyjną, inni widzą ratunek w instytucjach i mechanizmach demokracji deliberacyjnej lub w połączeniu obydwu (Grygieńć 2017). Deliberacja w szerszej skali, w skali państwa, w erze fake newsów jest utrudniona, jeśli w ogóle możliwa. Ale zapewnejest możliwa w węższej skali, choćby w mini-publicznościach, zwłaszcza jeśli jest to wspierane przez ekspertów. Choć utopijny, ale warty przytoczenia jest radykalny pomysł na wyjście z kryzysu demokracji Markowskiego: "J edynym wyjściem z tej sytuacji byłaby zmiana języka: zjęzyka wartości najęzyk sensu, zjęzyka opinii na język interpretacji, z języka uczuć na język argumentacji” (Markowski 2019: 16)7.

Równie utopijny, bo zakładający dużą przemianę kulturową jest pomysł Fukuyamy, odejście od narcystycznej, indywidualistycznej kultury wzmacniania „ja” do uznania wagi zespalających wspólnotę cnót

\footnotetext{
${ }^{7}$ Autor dobrze zna życie polityczne i kulturę dwóch państw Polski i USA. Obserwuje zabójcze dla demokracji i niszczące kulturę polityczną długotrwałe „walki plemienne”. W roku 1992 na zjeździe republikanów, Pat Buchanan, ówczesny kandydat na prezydenta, ogłosił „wojny kulturowe” z liberałami. W roku 2016 wojna kulturowa była mocnym paliwem politycznym w kampanii Donalda Trumpa. Podobnie jest w Polsce. Cytat z wiersza Jarosława Rymkiewicza z roku 2010 można uznać za symboliczne ujęcie głębokiego podziału kulturowego w Polsce: „Dwie Polski - jedna chce się podobać na świecie. I ta druga, ta którą wiozą na lawecie”. Politycznym odpowiednikiem z kampanii parlamentarnej w roku 2006 jest deklaracja podziału na Polskę solidarną i Polskę liberalną.
} 
obywatelskich. „Demokracja liberalna jest domyślnym kontraktem między obywatelami a ich rządem i między samymi obywatelami, zgodnie zktórym rezygnują oni z pewnych praw, aby rząd mógł chronić inne, fundamentalne" (Fukuyma 2019: 165).

Literatura

Antoszewski, A. (2016). Wspótczesne teorie demokracji. Warszawa: Wydawnictwo Sejmowe.

Diamond, L. (2008). The Democratic Rollback: The Resurgence of the Predatory State. Foreign Affairs, 87(2), 36-48.

Flis, D. (2020, 23 stycznia). „The Economist”: W rankingu demokracji Polska po raz pierwszy niżej niż Węgry. Oko.press. https://oko. press/ the-economist-w-rankingu-demokracji-polska-po-raz-pierwszy-nizej-niz-wegry/ [11.11.2020]

Fukuyama, F. (2019). Tożsamość. Wspótczesna polityka tożsamościowa i walka o uznanie. Dom Wydawniczy Rebis: Poznań.

Gdula, M. (2018). Nowy autorytaryzm. Warszawa: Wydawnictwo Krytyki Politycznej.

Grygieńć, J. (2017). Demokracja na rozdrożu. Deliberacja czy partycypacja polityczna?. Kraków: Universitas.

Held, D. (2010). Modele demokracji. Kraków: Wydawnictwo Uniwersytetu J agiellońskiego.

Hochschild, A. (2017). Obcy we wtasnym kraju. Gniew i żal amerykańskiej prawicy. Warszawa: Wydawnictwo Krytyki Politycznej.

Huntington, S. (2009) Trzecia fala demokratyzacji. Warszawa: Wydawnictwo Naukowe PWN.

Inglehart, R. (1977) The Silent Revolution: Changing Values and Political Styles Among Wester Publics. Princeton: Princeton University Press.

Inglehart, R., Norris, P. (2009). Wzbierająca fala. Równouprawnienie płci a zmiana kulturowa na świecie. Warszawa: PIW. 
Lilla, M. (2018) Koniec liberalizmu, jaki znamy. Requiem dla polityki tożsamości. Warszawa: Wydawnictwo Fundacja Kultura Liberalna. Marczewski, P. (2017). Partie polityczne a jakość polskiej demokracji. Warszawa: Fundacja im. Stefana Batorego. https:// www.batory.org. pl/upload/ files/ Programy\%20operacyjne/ Masz\%20Glos/ Partie\% 20polityczne\%20a\%20jakosc\%20polskiej\%20demokracji.pdf [11.11.2020]

Markowski, M.P. (2019). Wojny nowoczesnych plemion. Spór o rzeczywistość w epoce populizmu. Kraków: Karakter.

Nalewajko, E. (1997). Protopartie i protosystem. Szkic do obrazu polskiej wielopartyjności. Warszawa: Wydawnictwo ISP PAN.

Pańków, I., Pańków, J . (2010). Polityka jako sztuka skutecznego rzqdzenia: Niccolo Machiavelli. [w:] Koncepcje polityki. (red.) Wesolowski, W. Warszawa: Wydawnictwo Naukowe SCHOLAR, 127-158.

Rahat, G., Kenig, O. (2018). From Party Politics to Personalized Politics? Party Change and Political Personalization in Democracies. Oxford: Oxford University Press.

Repucci, S. (2020). Freedom in the World 2020: A Leaderless Struggle for Democracy. Freedom House. https:/ / freedomhouse.org/report/ freedom-world/2020/leaderless-struggle-democracy [11.11.2020]

Rosanvallon, P. (2011). Kontrdemokracja. Polityka $w$ dobie nieufności. Wrocław: Wydawnictwo Naukowe Dolnośląskiej Szkoły Wyższej.

Trzciński, K. (2016). „Demokracja o niskiej jakości” (low-quality democracy) - zasadność stosowania pojęcia i Horowitzowska egzemplifikacja na przykładzie Indonezji. Studia Polityczne, 4, 167-191.

Wesołowski, W. (2000). Partie: nieustanne klopoty. Warszawa: Wydawnictwo IFiS PAN. 